\title{
3-Nitrotriazole-based piperazides as potent antitrypanosomal agents
}

\author{
Maria V. Papadopoulou ${ }^{\mathrm{a} *}$, William D. Bloomer ${ }^{\mathrm{a}}$, Howard S. Rosenzweig ${ }^{\mathrm{b}}$, Ivan P. \\ O’Shea ${ }^{\mathrm{c}}$ Shane R. Wilkinson ${ }^{\mathrm{c}}$, Marcel Kaiser ${ }^{\mathrm{d}, \mathrm{e}}$
}

${ }^{\mathrm{a} N o r t h S h o r e ~ U n i v e r s i t y ~ H e a l t h S y s t e m, ~ E v a n s t o n, ~ I L, ~ U S ; ~}{ }^{\mathrm{b}}$ Oakton Community College, Des Plaines, IL, US; ${ }^{\mathrm{c}}$ School of Biological \& Chemical Sciences, Queen Mary University of London, London, UK; ${ }^{\mathrm{d}}$ Swiss Tropical and Public Health Institute, Parasite Chemotherapy, Basel, Switzerland; ${ }^{\mathrm{e} U n i v e r s i t y ~ o f ~ B a s e l, ~ B a s e l, ~ S w i t z e r l a n d . ~}$

*Correspondence to: Maria V. Papadopoulou, Ph.D., NorthShore University HealthSystem, Department of Radiation Medicine, 2650 Ridge Ave., Evanston IL, 60201, USA.

Tel: (847)570-2262; Fax: (847)570-1878

e-mail: mpapadopoulou@northshore.org

Running Title: Nitrotriazole-based piperazides as antiparasitic agents

${ }^{1}$ Abbreviations: NTD, Neglected tropical diseases; T. brucei, Trypanosoma brucei; HAT, human African trypanosomiasis; T. cruzi, Trypanosoma cruzi; Bnz, benznidazole (N-benzyl-2(2-nitro-1H-imidazol-1-yl)acetamide); Nfx, nifurtimox $\quad$ (4-(5-nitrofurfurylindenamino)-3methylthio-morpholine-1,1-dioxide); NTR, type I nitroreductase; TcNTR, T. cruzi NTR; TbNTR, T. brucei NTR; CYP51, sterol 14 $\alpha$-demethylase enzyme; TcCYP51, T. cruzi CYP51; $\mathrm{IC}_{50}$, concentration for $50 \%$ growth inhibition; SI, selectivity index; SAR, structure-activity relationships; TDR, Tropical Diseases Research (http://www.who.int/tdr/en/). 
Abstract: Novel linear 3-nitro-1H-1,2,4-triazole-based piperazides were synthesized and evaluated as antitrypanosomal agents. In addition, some bisarylpiperazine-ethanones which were formed as by-products were also screened for antiparasitic activity. Most 3-nitrotriazole- based derivatives were potent and selective against $T$. cruzi parasites, but only one displayed these desired properties against T. b. rhodesiense. Moreover, two 3-nitrotriazole-based chlorophenylpiperazides were moderately and selectively active against L. donovani. Although the bisarylpiperazine-ethanones were active or moderately active against $T$. cruzi, none of them demonstrated an acceptable selectivity. In general, 3-nitrotriazole-based piperazides were less toxic to host L6 cells than the previously evaluated 3-nitrotriazole-based piperazines and seven of 13 were 1.54- to 31.2-fold more potent antichagasic agents than the reference drug benznidazole. Selected compounds showed good ADMET characteristics. One potent in vitro antichagasic compound (3) was tested in an acute murine model and demonstrated antichagasic activity after a 10-day treatment of $15 \mathrm{mg} / \mathrm{kg} /$ day. However, neither compound 3 nor benznidazole showed a statistically significant $P$ value compared to control due to high variability in parasite burden among the untreated animals. Working as prodrugs, 3-nitrotriazolebased piperazides were excellent substrates of trypanosomal type I nitroreductases and constitute a novel class of potentially effective and more affordable antitrypanosomal agents.

Key words: Nitrotriazoles; piperazides; trypanocidal; leishmanicidal; Chagas disease. 


\section{Introduction}

American trypanosomiasis (Chagas disease), human African trypanosomiasis (HAT) and leishmaniasis are caused by parasitic infections and constitute major health problems in poor countries worldwide. They are considered 'neglected' because they have received limited funding for discovery, development and delivery of new therapies. African trypanosomiasis is endemic in many sub-Saharan African countries and is caused by Trypanosoma brucei rhodesiense and Trypanosoma brucei gambiense. Chagas disease affects populations in South and Central America and is caused by Trypanosoma cruzi, whereas leishmaniasis, caused by more than 20 Leishmania species, occurs throughout tropical and sub-tropical regions [1]. It is estimated that together these three diseases infect approximately 20 million people and are responsible for more than 110,000 deaths per year [2].

Currently available pharmaceuticals for the treatment of neglected diseases suffer from poor efficacy, toxic side effects, high cost, the need for intravenous administration in certain cases, long duration of treatment, and the emergence of resistance. For example, severe toxicity and long treatment requirements are associated with nifurtimox (nfx) and benznidazole (bnz), the two medications used against Chagas disease in its initial acute stage [3, 4]. Similarly, drugs used to treat HAT disease and leishmaniasis are highly toxic and/or are based on i.v. administration (e.g., eflornithine, antimony- and arsenic-based compounds) resulting in severe side effects, or are of high cost (e.g,. eflornithine, liposomal amphotericin B, miltefosine, and paromomycin) [5-7]. Therefore, new effective, safe and affordable drugs are urgently needed for the treatment of these neglected tropical diseases.

Although inhibitors of the fungal sterol $14 \alpha$-demethylase enzyme (CYP51) and of the orthologous enzyme T. cruzi CYP51 (TcCYP51) demonstrated promising efficacy against 
Chagas disease in preclinical studies [8-13], data from clinical trials using posaconazole were proved disappointing [14]. Recent evidence indicates that nitroheterocyclics might be more efficacious trypanocidal agents than CYP51 inhibitors [15], and combination treatments of nitroheterocyclics with CYP51 inhibitors might offer a better solution [16].

We have shown that several chemical classes of 3-nitro-1H-1,2,4-triazole-based compounds exhibit excellent antichagasic activity both in vitro and in vivo; furthermore, appreciable antiHAT activity was observed in vitro with several such analogs [17-22]. Interestingly, 3nitrotriazole-based compounds are significantly more potent and less toxic than their 2nitroimidazole-based counterparts [17-23], with part of the trypanocidal activity being dependent on the parasite's expression of a mitochondrially targeted, oxygen-insensitive type I nitroreductase (NTR), an enzyme absent from most other eukaryotes [17, 18, 20-22]. Type I NTRs, via a series of 2 electron reduction reactions leading to the production of toxic metabolites, is responsible for the trypanocidal activity of $\mathrm{Nfx}, \mathrm{Bnz}$ and other nitroheterocyclic prodrugs [24-27].

Among the chemical classes of 3-nitro-1H-1,2,4-triazole-based compounds studied as antitrypanosomal agents, several piperazine- and amide-analogs were of exceptional antichagasic activity [18-20]. However, 3-nitrotriazole-based piperazines tend to be more toxic than 3nitrotriazole-based amides. In addition, 3-nitrotriazole-based amides demonstrate excellent ADMET characteristics [20, 22]. Therefore, we decided to investigate 3-nitrotriazole-based piperazides as antitrypanosomatid agents with potentially improved characteristics. The synthesis and biological evaluation of such compounds is described in the present work. In addition, some bisarylpiperazine-ethanones, which were produced during the synthesis of the piperazides as byproducts, were also evaluated as antitrypanosomal agents. 


\section{Results and Discussion}

\section{Chemistry}

The structures of tested compounds are shown in Table 1. Piperazides 2-14 were prepared in good yields by nucleophilic substitution of chloroacetylpiperazides 1a-I with the potassium salt of 3-nitrotriazole (or 2-nitroimidazole in one case) under refluxing conditions. Chloroacetylpiperazides 1a-I and bisarylpiperazine-ethanones 15-19 were formed in the same reaction between chloroacetylchloride and an appropriate piperazine. When the reaction time was short (2 h), only the chloroacetylpiperazides 1a-l were formed by nucleophilic substitution of the acylchloride. At longer reaction times (usually $24 \mathrm{~h}$ ) nucleophilic substitution of the alkylchloride also took place, and the bisarylpiperazine-ethanones 15-19 were formed in addition to chloroacetylpiperazides 1a-I (Scheme 1).

\section{Biological Evaluation.}

Anti-parasitic activity and toxicity. Compounds were tested for antiparasitic activity against $T$. cruzi amastigotes, bloodstream form (BSF) of T. b. rhodesiense and L. donovani axenic amastigotes and, for toxicity in L6 rat skeletal myoblasts, the host cells for T. cruzi amastigotes. Dose response curves were constructed from which the concentration of compound that inhibits parasite or mammalian cell growth by $50 \%$ ( $\left.\mathrm{IC}_{50}\right)$ was calculated (Table 1). Selectivity index (SI) for each compound towards each parasite was calculated from the equation: SI = $\mathrm{IC}_{50 \mathrm{~L} 6} / \mathrm{IC}_{50 \text { parasite }}$ (Table 1). According to the TDR (Special Programme for Research and Training in Tropical Diseases, World Health Organization) criteria for antiparasitic activity and selectivity, an $\mathrm{IC}_{50}$ of $<4.0 \mu \mathrm{M}$, between $4.0-60 \mu \mathrm{M}$ or $>60 \mu \mathrm{M}$, denotes 'active', 'moderately 
active' or 'inactive' compounds, respectively, against $T$. cruzi amastigotes, whereas a SI of $\geq 50$ is required; for blood stream form (BSF) T. $b$. rhodesiense, $\mathrm{IC}_{50}$ values of $<0.5 \mu \mathrm{M}$, between 0.5$6.0 \mu \mathrm{M}$ or $>6.0 \mu \mathrm{M}$ identify 'active', 'moderately active' or 'inactive' compounds, respectively, whereas a SI value of $\geq 100$ is desired; finally, for $L$. donovani amastigotes, $\mathrm{IC}_{50}$ of $<1 \mu \mathrm{M}$, between 1.0-6.0 $\mu \mathrm{M}$ or $>6.0 \mu \mathrm{M}$, provides 'active', 'moderately active' or 'inactive' compounds, respectively, whereas a SI value of $\geq 20$ is ideal [28]. Most (9 of 12) of the 3-nitrotriazole-based piperazides tested were deemed to be 'active' antichagasic agents, one was 'active' anti-HAT agent and two of them moderately active antileishmanial agents, all displaying an acceptable selectivity (Table 1). Although the bisarylpiperazine-ethanones were active or moderately active against $T$. cruzi, none demonstrated acceptable selectivity (Table 1).

\subsubsection{SAR analysis for antichagasic activity}

The arylpiperazides (2-7) exhibited appreciative antichagasic activity with $\mathrm{IC}_{50}$ values ranging between $169 \mathrm{nM}$ to $2.85 \mu \mathrm{M}$. There was a direct correlation between activity and the compound's lipophilicity with most lipophilic dichlorophenylpiperazide 3 being the most potent agent of this sub-group (Table 1). In addition, compound $\mathbf{3}$ demonstrated the greatest selectivity $(\mathrm{SI}=641)$, despite the fact that it was the most toxic analog of the subgroup against L6 cells (Table 1).

The two 3-nitrotriazole-based heteroarylpiperazides (8 and $\mathbf{9}$ ) were moderately active, according to the criteria set, but with unacceptable selectivity. Therefore, introducing heteroatoms in the phenyl group of arylpiperazides reduced antichagasic activity, most likely due to decreased lipophilicity, and, thus, selectivity (Table 1). When the 3-nitrotriazole ring in 9 was replaced with a 2-nitroimidazole ring in $\mathbf{1 0}$, the activity was completely lost irrespective of lipophilicity (Table 1). 
Antichagasic activity increased in benzylpiperazides (11-13) with the most lipophilic compound 13 exhibiting an $\mathrm{IC}_{50}$ of $73 \mathrm{nM}$ against $T$. cruzi. However, and despite a SI of 302, the high lipophilicity of $\mathbf{1 3}(\operatorname{cog} \mathrm{P}=3.102)$ resulted in an $\mathrm{IC}_{50}$ of ca. $22 \mu \mathrm{M}$ in L6 cells, designating it as the most toxic analog among all tested piperazides (Table 1). Finally, introducing a second amide in $\mathbf{1 4}$, also abolished antichagasic activity (Table 1).

The above SAR clearly shows that independently of variations in structure among all 3nitrotriazole-based piperazides tested, there was very good correlation between lipophilicity (clogP values) and antichagasic activity ( $\mathrm{IC}_{50}$ against $T$. cruzi). The correlation is described by a $2^{\text {nd }}$ degree polynomial equation and the $\mathrm{R}^{2}$ value was 0.97 (Fig. 1). Other physical characteristics of each structure such as electronegativity of the substituent on the phenyl ring or polar surface area (PSA) did not play a major role in the anti-chagasic activity although those compounds that had the lowest PSA values exhibited the lower IC $_{50}$ values against $T$. cruzi (Table 1). Several analogs (2-5, 11-13) were from 1.5 to 31-fold more potent than benznidazole.

With regard to bisarylpiperazine-ethanones (15-19), the active derivatives 16 and 17 violate 2 of the Lipinski rules of 5 (MW and clogP), while compound 15 violates one rule (clogP). The antichagasic activity of $\mathbf{1 5 - 1 7}$ is most likely related to high lipophilicity coupled with their low PSA value; however, these properties also contribute to the high toxicity of $\mathbf{1 6}$ and $\mathbf{1 7}$ and the unacceptable selectivity of $\mathbf{1 5 - 1 7}$ towards $T$. cruzi parasite (Table 1 ). The two remaining bisarylpiperazine-ethanones $\mathbf{1 8}$ and $\mathbf{1 9}$ are moderately active against $T$. cruzi, but also had poor SI values towards this parasite.

\subsubsection{Analysis of anti-HAT activity}


Displaying an $\mathrm{IC}_{50}$ value of $231 \mathrm{nM}$ and a SI of 260, only the dichlorobenzylpiperazide 12 was selectively active against $T$. $b$. rhodesiense (Table 1). Four additional 3-nitrotriazole-based piperazides (3, 4, 11 and 13) exhibited moderate anti-HAT activity, but had unacceptable selectivity (Table 1). As observed with antichagasic activity (with the exception of compound 2), there was good correlation between clogP values and anti-HAT activity among 3-nitrotriazolebased piperazides (data not shown). None of the bisarylpiperazine-ethanones (15-19) exhibited anti-HAT activity according to TDRs set criteria (Table 1).

\subsubsection{Analysis of antileishmanial activity}

Two arylpiperazides $(3,4)$ and one benzylpiperazide $(\mathbf{1 3})$ exhibited moderate but appreciable antileishmanial activity with $\mathrm{IC}_{50}$ values against $L$. donovani axenic amastigotes $<2 \mu \mathrm{M}$. However, only compounds $\mathbf{3}$ and $\mathbf{4}$ demonstrated acceptable selectivity towards the parasite (Table 1). Once again, lipophilicity seems to be the driving force for the leishmanicidal activity.

One bisarylpiperazine-ethanone (17) exhibited moderate antileishmanial activity, but with an unacceptable SI value of 6 . Since $\mathbf{1 7}$ does not demonstrate the highest clogP value among ethanones, it is not clear whether or not lipophilicity is the only factor contributing to antileishmanial activity.

\subsubsection{Involvement of type I Nitroreductase}

Representative 3-nitrotriazole-based piperazides $(2-5,9,11-13)$ were evaluated as substrates of purified, recombinant trypanosomal NTRs and compared to benznidazole (Table 2). Enzyme specific activity was measured as oxidized NADH per min per mg of protein. All tested compounds were excellent substrates of both TcNTR and TbNTR. When tested against the T. cruzi enzyme, the selected compounds were metabolized at rates comparable or slightly better than that of Bnz 
while the $T$. $b$. brucei enzyme could reduce the same analogs at rates 1.3 to 2.5 -fold higher than the reference 2-nitroimidazole (Table 2).

To determine whether NTR plays a role in metabolizing the substrates within the parasite, the above subset of 3-nitrotriazole-based piperazides were tested against BSF T. b. brucei. In initial screens, 2, 5 and $\mathbf{9}$ did not affect the growth of wild type parasites at concentrations up to the 30 $\mu \mathrm{M}$ and these were not analyzed further (Table 3).

For the remaining compounds T. $b$. brucei engineered to express elevated levels of TbNTR were shown to be ca. 4- to 17 -fold more susceptible to the 3-nitrotriazole-based piperazides under study than parasites expressing wild type levels of the enzyme, with 3, 4, 11 and 12 generating a $\geq 7$-fold shift in parasite sensitivity: $\mathrm{nfx}$ tested in parallel generated a 10-fold difference in $\mathrm{IC}_{50}$ values. For these four structures that demonstrate activity against $T$. cruzi and T. rhodesiense (Table 1), this difference in sensitivity indicates that all function as prodrugs in the parasite itself with NTR playing a key role in their activation. When TbNTR/TcNTR enzymatic activity and anti-trypanosomal activity were compared no obvious correlation was observed possibly due to existence of additional targets in the trypanosome, permeability issues with regard to mitochondrion, compound stability and pharmacokinetic factors in general.

\subsubsection{ADMET studies}

Limited ADMET studies were performed with compounds $\mathbf{1 1}$ and $\mathbf{1 2}$ to check metabolic stability, Caco-2 permeability and cytochrome P450 inhibition. These two compounds were shown to be relatively stable with half lives $\left(T_{1 / 2}\right)$ of $>180$ and 72 min, respectively, in the presence of NADPH and $\mathrm{T}_{1 / 2}$ of $>180$ and 174 min, respectively, in the absence of NADPH (Table 4). Neither compound inhibited CYP3A4, CYP2C9, CYP2D6, CYP2C19 and CYP2C8, 
demonstrating an $\mathrm{IC}_{50}>20 \mu \mathrm{M}$ for all enzymes (data not shown). Both compounds exhibited very good Caco-2 permeability with efflux ratios ( $\mathrm{Re}$ ) of 0.97 and 0.91 , respectively (Table 5).

\subsubsection{In vivo antichagasic activity}

The 3-nitrotriazole-based dichlorophenyl piperazide 3 was selected for in vivo evaluation because of its good in vitro antichagasic activity ( $\mathrm{IC}_{50}$ of $169 \mathrm{nM}$ against $T$. cruzi), excellent selectivity (SI of 641, the highest in the series) and relatively low toxicity (IC $\mathrm{I}_{50}$ in L6 cells of 108.4 $\mu \mathrm{M}$ ). Groups of 5 mice each were treated i.p. with compound 3 or bnz, at $15 \mathrm{mg} / \mathrm{kg} / \mathrm{day} \mathrm{x}$ 10 days. The mean ratio of parasite levels was calculated after 10 days of treatment. The data are summarized in Fig. 2. No apparent toxicity was observed at the given dose and time-frame for compound 3, which reduced the parasite ratio by $77 \%$ after 10-day treatment; the corresponding reduction by bnz was $99 \%$. However, this reduction was not statistically significant for either compound 3 or bnz due to high variability in parasite burden among the untreated animals.

\section{Conclusions}

Piperazide-based compounds demonstrate a broad range of biological activities including, but not limited to, antibacterial, antiparasitic, antifungal, anthelmintic and antitubercular activity [2933]. In particular, some metronidazole-bearing piperazides exhibit appreciable antigiardial and/or antitrichomonal activity [31]. In addition, aryloxyphenyl piperazides have been described as histamine $\mathrm{H}_{3}$ antagonists and serotonin reuptake inhibitors for the treatment of depression [34], while other piperazine amides are considered useful for the treatment of obesity or diabetes [35, 36]. 
Our novel 3-nitrotriazole-based aryl- and benzylpiperazides were potent and selective antichagasic agents in vitro. In addition, two such analogs $(3,4)$ exhibited moderate but selective antileishmanial activity, while another analog (12) demonstrated remarkable anti-HAT activity in vitro. The antitrypanosomal activities of tested compounds were attributed, at least in part, to their high lipophilicity and their activation by the type I nitroreductases. 3-Nitrotriazole-based heteroarylpiperazides, dipiperazides and bisarylpiperazine-ethanones were varyingly active, but toxic antichagasic agents in vitro. Although in vivo antichagasic activity was demonstrated with compound 3, the data were not of statistical significance due to high variability in parasite burden among the untreated animals. However, favorable ADMET studies with two analogs (11, 12) and lack of mutagenicity or developmental toxicity in previously studied 3-nitrotriazolebased amides [20, 23] suggest that 3-nitrotriazole-based aryl/benzylpiperazides could be of real value in the treatment of Chagas disease, provided that further in vivo evaluation in the chronic mouse model is successful.

\section{Experimental}

\subsection{Chemistry}

\subsubsection{General}

All starting materials and solvents purchased from Sigma-Aldrich (Milwaukee, WI), were of research-grade quality and used without further purification. Solvents used were anhydrous and the reactions were carried out under a nitrogen atmosphere and exclusion of moisture. Melting points were determined by using a Mel-Temp II Laboratory Devices apparatus (Holliston, MA) and are uncorrected. Proton NMR spectra were obtained on a Varian Inova-500 or an Agilent Hg-400 spectrometer at 500 or $400 \mathrm{MHz}$, respectively, and are referenced to $\mathrm{Me}_{4} \mathrm{Si}$ or to the 
corresponding solvent, if the solvent was not $\mathrm{CDCl}_{3}$. High-resolution electrospray ionization (HRESIMS) mass spectra were obtained on a Agilent 6210 LC-TOF mass spectrometer at 11000 resolution. Thin-layer chromatography was carried out on aluminum oxide $\mathrm{N} / \mathrm{UV}_{254}$ or polygram silica gel G/UV 254 coated plates $(0.2 \mathrm{~mm}$, Analtech, Newark, DE). Chromatography was carried out on preparative TLC alumina GF (1000 microns) or silica gel GF (1500 microns) plates (Analtech). All compounds were purified by preparative TLC chromatography on silica gel or alumina plates and also checked by HPLC ( $\geq 95 \%$ purity).

4.1.2. Synthesis of chloroacetylpiperazides 1a-l: Compounds 1a-l and compounds 15-19 were synthesized in the same reaction: In a dichloromethane solution $(2-3 \mathrm{~mL})$ of chloroacetylchloride (1.1 eq), a dichloromethane solution $(8-10 \mathrm{~mL})$ of the appropriate piperazine (1 eq) and triethylamine (2.5 eq) was added dropwise and the reaction mixture was stirred overnight at room temperature under a nitrogen atmosphere. The reaction mixture was evaporated and the residue was extracted with ethyl acetate-brine. The organic layer was dried over $\mathrm{Na}_{2} \mathrm{SO}_{4}$ and chromatographed on silica preparative TLC to give the desired products. When the reaction was run for $2 \mathrm{~h}$, compounds 1a-l were the main products (>90\%). Compounds 1a-l are known in the literature and their spectroscopic data are provided in the supplementary material.

4.1.3. Synthesis of compounds 2-14: The potassium salt of 3-nitro-1,2,4-triazole or 2nitroimidazole (1 eq) was formed in $\mathrm{CH}_{3} \mathrm{CN}$ (6-10 mL), by refluxing with $\mathrm{KOH}(1.2 \mathrm{eq})$ for 30 min. To this suspension 1a-l (1.1 eq) was added and the reaction mixture was refluxed under a nitrogen atmosphere for $9 \mathrm{~h}$. If chloride $\mathbf{1}$ was an oil, it was added in $\mathrm{CH}_{3} \mathrm{CN}$ solution. The reaction mixture was checked by TLC for completion of the reaction and the solvent was 
evaporated. The residue was redissolved in ethyl acetate or acetone and the inorganic salts were filtered away. Upon preparative TLC (usually on silica gel; ethyl acetate-petroleum ether), the desired product was obtained as a powder. Purity was checked also by HPLC and it was $\geq 95 \%$.

4.1.3.1. 1-(4-(4-Chlorophenyl)piperazin-1-yl)-2-(3-nitro-1H-1,2,4-triazol-1-yl)ethanone (2): Yellow powder (77\%): mp $226{ }^{\circ} \mathrm{C}(\mathrm{dec}) ;{ }^{1} \mathrm{H}$ NMR $\left(400 \mathrm{MHz},\left(\mathrm{CD}_{3} \mathrm{COCD}_{3}+\mathrm{a}\right.\right.$ drop of DMSO6d) $\delta: 8.66$ (s, 1H), 7.26 (d, $J=8.8 \mathrm{~Hz}, 2 \mathrm{H}), 7.03$ (d, $J=8.8 \mathrm{~Hz}, 2 \mathrm{H}), 5.59$ (s, 2H), 3.80 (t, $J=$ $5.2 \mathrm{~Hz}, 2 \mathrm{H}), 3.73(\mathrm{t}, J=5.2 \mathrm{~Hz}, 2 \mathrm{H}), 3.35$ (t, $J=5.2 \mathrm{~Hz}, 2 \mathrm{H}), 3.23(\mathrm{t}, J=5.2 \mathrm{~Hz}, 2 \mathrm{H})$. HRESIMS calcd for $\mathrm{C}_{14} \mathrm{H}_{16} \mathrm{ClN}_{6} \mathrm{O}_{3}$ and $\mathrm{C}_{14} \mathrm{H}_{15} \mathrm{ClN}_{6} \mathrm{NaO}_{3} \mathrm{~m} / z[\mathrm{M}+\mathrm{H}]^{+}$and $[\mathrm{M}+\mathrm{Na}]^{+} 351.0967$ and 373.0786, 375.0762 found 351.0964 and 373.0786, 375.0752.

4.1.3.2. 1-(4-(3,4-Dichlorophenyl)piperazin-1-yl)-2-(3-nitro-1H-1,2,4-triazol-1-yl)ethanone (3): Yellow crystals (78\%): mp 130-132 ${ }^{\circ} \mathrm{C}(\mathrm{dec}) ;{ }^{1} \mathrm{H}$ NMR (400 MHz, $\left(\mathrm{CD}_{3} \mathrm{COCD}_{3}\right) \delta: 8.60$ (s, $\left.1 \mathrm{H}\right)$, 7.39 (d, $J=8.8 \mathrm{~Hz}, 1 \mathrm{H}), 7.16$ (d, $J=3.2 \mathrm{~Hz}, 1 \mathrm{H}), 7.00$ (dd, $J=8.8,3.2 \mathrm{~Hz}, 1 \mathrm{H}), 5.59$ (s, 2H), $3.84(\mathrm{t}, J=5.2 \mathrm{~Hz}, 2 \mathrm{H}), 3.75$ (t, $J=5.2 \mathrm{~Hz}, 2 \mathrm{H}), 3.44$ (t, $J=5.2 \mathrm{~Hz}, 2 \mathrm{H}), 3.31$ (t, $J=5.2 \mathrm{~Hz}$, 2H). HRESIMS calcd for $\mathrm{C}_{14} \mathrm{H}_{15} \mathrm{Cl}_{2} \mathrm{~N}_{6} \mathrm{O}_{3} \mathrm{~m} / \mathrm{z}[\mathrm{M}+\mathrm{H}]^{+}$385.0577, 387.0550, found 385.0578, 387.0549.

4.1.3.3. 2-(3-Nitro-1H-1,2,4-triazol-1-yl)-1-(4-(4-(trifluoromethyl)phenyl)piperazin-1-yl) ethanone (4): Off white powder (74 \%): mp $224{ }^{\circ} \mathrm{C}(\mathrm{dec}) ;{ }^{1} \mathrm{H}$ NMR $\left(400 \mathrm{MHz},\left(\mathrm{CD}_{3} \mathrm{COCD}_{3}\right) \delta\right.$ : 8.60 (s, 1H), 7.55 (d, $J=9.2 \mathrm{~Hz}, 2 \mathrm{H}), 7.14$ (d, $J=9.2 \mathrm{~Hz}, 2 \mathrm{H}$ ), 5.59 (s, 2H), 3.86 (t, $J=5.2 \mathrm{~Hz}$, 
2H), $3.76(\mathrm{t}, J=5.2 \mathrm{~Hz}, 2 \mathrm{H}), 3.54(\mathrm{t}, J=5.2 \mathrm{~Hz}, 2 \mathrm{H}), 3.42(\mathrm{t}, J=5.2 \mathrm{~Hz}, 2 \mathrm{H})$. HRESIMS calcd for $\mathrm{C}_{15} \mathrm{H}_{16} \mathrm{~F}_{3} \mathrm{~N}_{6} \mathrm{O}_{3} \mathrm{~m} / \mathrm{z}[\mathrm{M}+\mathrm{H}]^{+}$385.1230, found 385.1237.

4.1.3.4. 2-(3-Nitro-1H-1,2,4-triazol-1-yl)-1-(4-(p-tolyl)piperazin-1-yl)ethanone (5): Yellow powder (70 \%): mp 172-174 ${ }^{\circ} \mathrm{C}(\mathrm{dec}) ;{ }^{1} \mathrm{H}$ NMR $\left(400 \mathrm{MHz},\left(\mathrm{CD}_{3} \mathrm{COCD}_{3}\right)\right.$ \&: 8.60 (s, 1H), 7.07 (d, $J=8.4 \mathrm{~Hz}, 2 \mathrm{H}), 6.91$ (d, $J=8.4 \mathrm{~Hz}, 2 \mathrm{H}), 5.57$ (s, 2H), 3.80 (t, $J=5.2 \mathrm{~Hz}, 2 \mathrm{H}), 3.72(\mathrm{t}, J=$ $5.2 \mathrm{~Hz}, 2 \mathrm{H}$ ), 3.26 (t, $J=5.2 \mathrm{~Hz}, 2 \mathrm{H}), 3.15(\mathrm{t}, J=5.2 \mathrm{~Hz}, 2 \mathrm{H})$. HRESIMS calcd for $\mathrm{C}_{15} \mathrm{H}_{19} \mathrm{~N}_{6} \mathrm{O}_{3}$ $m / z[\mathrm{M}+\mathrm{H}]^{+}$331.1513, found 331.1516.

4.1.3.5. 1-(4-(4-Methoxyphenyl)piperazin-1-yl)-2-(3-nitro-1H-1,2,4-triazol-1-yl)ethanone (6). This compound is listed in the Aurora Screening Library but no reference is available: Orange powder (88 \%): mp 181-183 ${ }^{\circ} \mathrm{C}(\mathrm{dec}) ;{ }^{1} \mathrm{H}$ NMR (400 MHz, $\left(\mathrm{CD}_{3} \mathrm{COCD}_{3}\right)$ 8: 8.60 (s, $\left.1 \mathrm{H}\right), 6.97$ (d, $J=8.8 \mathrm{~Hz}, 2 \mathrm{H}), 6.85$ (d, $J=9.2 \mathrm{~Hz}, 2 \mathrm{H}), 5.57$ (s, 2H), 3.79 (t, $J=5.0 \mathrm{~Hz}, 2 \mathrm{H}), 3.74$ (s, 3H), $3.72(\mathrm{t}, J=5.2 \mathrm{~Hz}, 2 \mathrm{H}), 3.19(\mathrm{t}, J=5.0 \mathrm{~Hz}, 2 \mathrm{H}), 3.08(\mathrm{t}, J=5.2 \mathrm{~Hz}, 2 \mathrm{H})$. HRESIMS calcd for $\mathrm{C}_{15} \mathrm{H}_{19} \mathrm{~N}_{6} \mathrm{O}_{4}$ and $\mathrm{C}_{15} \mathrm{H}_{18} \mathrm{~N}_{6} \mathrm{NaO}_{4} \mathrm{~m} / \mathrm{z}[\mathrm{M}+\mathrm{H}]^{+}$and $[\mathrm{M}+\mathrm{Na}]^{+} 347.1462$ and 369.1282 found 347.1466 and 369.1283.

4.1.3.6. 2-(4-(2-(3-Nitro-1H-1,2,4-triazol-1-yl)acetyl)piperazin-1-yl)benzonitrile (7): Off white powder (79 \%): mp 92-94 ${ }^{\circ} \mathrm{C}(\mathrm{dec}) ;{ }^{1} \mathrm{H}$ NMR $\left(400 \mathrm{MHz}, \mathrm{CD}_{3} \mathrm{COCD}_{3}\right) \delta: 8.61$ (s, $\left.1 \mathrm{H}\right), 7.70$ (dd, $J$ $=8.0,1.6 \mathrm{~Hz}, 1 \mathrm{H}), 7.63$ (ddd, $J=8.4,7.2,1.6 \mathrm{~Hz}, 1 \mathrm{H}), 7.23(\mathrm{~d}, J=8.4 \mathrm{~Hz}, 1 \mathrm{H}), 7.17$ (ddd, $J=$ 8.4, 7.2, $0.8 \mathrm{~Hz}, 1 \mathrm{H}), 5.60$ (s, 2H), 3.88 (t, $J=5.2 \mathrm{~Hz}, 2 \mathrm{H}), 3.80(\mathrm{t}, J=5.2 \mathrm{~Hz}, 2 \mathrm{H}), 3.38$ (t, $J=$ $4.8 \mathrm{~Hz}, 2 \mathrm{H}), 3.25(\mathrm{t}, J=4.8 \mathrm{~Hz}, 2 \mathrm{H})$. HRESIMS calcd for $\mathrm{C}_{15} \mathrm{H}_{16} \mathrm{~N}_{7} \mathrm{O}_{3} \mathrm{~m} / \mathrm{z}[\mathrm{M}+\mathrm{H}]^{+} 342.1309$, found 342.1309. 
4.1.3.7. 2-(3-Nitro-1H-1,2,4-triazol-1-yl)-1-(4-(pyridin-2-yl)piperazin-1-yl)ethanone (8): White powder (67 \%): mp 108-109 ${ }^{\circ} \mathrm{C}$ (dec); ${ }^{1} \mathrm{H}$ NMR (400 MHz, $\left(\mathrm{CD}_{3} \mathrm{COCD}_{3}\right) \delta: 8.61$ (s, $\left.1 \mathrm{H}\right), 8.16$ (ddd, $J=4.8,2.0,0.8 \mathrm{~Hz}, 1 \mathrm{H}), 7.56$ (ddd, $J=10.8,7.2,2.0 \mathrm{~Hz}, 1 \mathrm{H}), 6.85$ (dd, $J=8.8,0.8 \mathrm{~Hz}$, 1H), 6.68 (ddd, $J=7.2,5.2,0.8 \mathrm{~Hz}, 1 \mathrm{H}), 5.58$ (s, 2H), 3.77 (m, 4H), 3.69 (m, 2H), 3.61 (m, 2H). HRESIMS calcd for $\mathrm{C}_{13} \mathrm{H}_{16} \mathrm{~N}_{7} \mathrm{O}_{3}$ and $\mathrm{C}_{13} \mathrm{H}_{15} \mathrm{~N}_{7} \mathrm{NaO}_{3} \mathrm{~m} / \mathrm{z}[\mathrm{M}+\mathrm{H}]^{+}$and $[\mathrm{M}+\mathrm{Na}]^{+} 318.1309$ and 340.1129 found 318.1313 and 340.1129.

4.1.3.8. 2-(3-Nitro-1H-1,2,4-triazol-1-yl)-1-(4-(pyrimidin-2-yl)piperazin-1-yl)ethanone (9): White crystals (79 \%): mp 106-108 ${ }^{\circ} \mathrm{C}$ (dec); ${ }^{1} \mathrm{H}$ NMR (400 MHz, $\left(\mathrm{CD}_{3} \mathrm{COCD}_{3}\right) \delta: 8.61$ (s, $\left.1 \mathrm{H}\right)$, 8.38 (d, $J=4.8 \mathrm{~Hz}, 2 \mathrm{H}), 6.65$ (t, $J=4.8 \mathrm{~Hz}, 1 \mathrm{H}), 5.59$ (s, 2H), 3.99 (br t, $J=5.4 \mathrm{~Hz}, 2 \mathrm{H}), 3.86$ (br t, $J=5.4 \mathrm{~Hz}, 2 \mathrm{H}$ ), 3.75 (br t, $J=5.4 \mathrm{~Hz}, 2 \mathrm{H}$ ), 3.67 (br t, $J=5.4 \mathrm{~Hz}, 2 \mathrm{H}$ ). HRESIMS calcd for $\mathrm{C}_{12} \mathrm{H}_{15} \mathrm{~N}_{8} \mathrm{O}_{3}$ and $\mathrm{C}_{12} \mathrm{H}_{14} \mathrm{~N}_{8} \mathrm{NaO}_{3} \mathrm{~m} / \mathrm{z}[\mathrm{M}+\mathrm{H}]^{+}$and $[\mathrm{M}+\mathrm{Na}]^{+} 319.1262$ and 341.1081 found 319.1268 and 341.1083.

4.1.3.9. 2-(2-Nitro-1H-imidazol-1-yl)-1-(4-(pyrimidin-2-yl)piperazin-1-yl)ethanone (10): Light yellow crystals (77 \%): mp 148-150 ${ }^{\circ} \mathrm{C}(\mathrm{dec}) ;{ }^{1} \mathrm{H}$ NMR $\left(400 \mathrm{MHz},\left(\mathrm{CD}_{3} \mathrm{COCD}_{3}\right) \delta: 8.38(\mathrm{~d}, J=\right.$ $4.8 \mathrm{~Hz}, 2 \mathrm{H}), 7.44$ (d, $J=1.0 \mathrm{~Hz}, 1 \mathrm{H}), 7.13$ (d, $J=1.0 \mathrm{~Hz}, 1 \mathrm{H}), 6.64$ (t, $J=4.8 \mathrm{~Hz}, 1 \mathrm{H}), 5.60$ (s, 2H), 3.97 (br t, $J=5.0 \mathrm{~Hz}, 2 \mathrm{H}$ ), 3.84 (br t, $J=5.4 \mathrm{~Hz}, 2 \mathrm{H}$ ), 3.74 (br t, $J=4.8 \mathrm{~Hz}, 2 \mathrm{H}$ ), 3.64 (br t, $J=4.8 \mathrm{~Hz}, 2 \mathrm{H})$. HRESIMS calcd for $\mathrm{C}_{13} \mathrm{H}_{16} \mathrm{~N}_{7} \mathrm{O}_{3}$ and $\mathrm{C}_{13} \mathrm{H}_{15} \mathrm{~N}_{7} \mathrm{NaO}_{3} \mathrm{~m} / z[\mathrm{M}+\mathrm{H}]^{+}$and $[\mathrm{M}+\mathrm{Na}]^{+}$ 318.1309 and 340.1129 found 318.1313 and 340.1136. 
4.1.3.10. 2-(3-Nitro-1H-1,2,4-triazol-1-yl)-1-(4-(4-(trifluoromethyl)benzyl)piperazin-1-yl) ethanone (11): White microcrystals (69\%): mp 162-164 ${ }^{\circ} \mathrm{C} ;{ }^{1} \mathrm{H}$ NMR $\left(400 \mathrm{MHz},\left(\mathrm{CD}_{3} \mathrm{Cl}\right) \delta\right.$ : 8.36 (s, 1H), 7.61 (d, $J=7.6 \mathrm{~Hz}, 2 \mathrm{H}), 7.46$ (d, $J=8.4 \mathrm{~Hz}, 2 \mathrm{H}), 5.16$ (s, 2H), 3.69 (t, $J=5.0 \mathrm{~Hz}$, 2H), 3.61 (s, 2H), 3.54 (t, $J=4.8, \mathrm{~Hz}, 2 \mathrm{H}), 2.54$ (t, $J=5.2 \mathrm{~Hz}, 2 \mathrm{H}), 2.50$ (t, $J=5.2 \mathrm{~Hz}, 2 \mathrm{H})$. HRESIMS calcd for $\mathrm{C}_{16} \mathrm{H}_{18} \mathrm{~F}_{3} \mathrm{~N}_{6} \mathrm{O}_{3} \mathrm{~m} / \mathrm{z}[\mathrm{M}+\mathrm{H}]^{+}$399.1387, found 399.1395 .

4.1.3.11. 1-(4-(3,4-Dichlorobenzyl)piperazin-1-yl)-2-(3-nitro-1H-1,2,4-triazol-1-yl)ethanone (12): White microcrystals (88 \%): mp 140-142 ${ }^{\circ} \mathrm{C} ;{ }^{1} \mathrm{H}$ NMR (400 MHz, $\left(\mathrm{CD}_{3} \mathrm{Cl}\right) \delta: 8.36$ (s, $\left.1 \mathrm{H}\right)$, 7.47 (d, $J=2.0 \mathrm{~Hz}, 1 \mathrm{H}), 7.41$ (d, $J=8.0 \mathrm{~Hz}, 1 \mathrm{H}), 7.17$ (dd, $J=8.4,2.0 \mathrm{~Hz}, 1 \mathrm{H}), 5.16$ (s, 2H), 3.68 (t, $J=4.8 \mathrm{~Hz}, 2 \mathrm{H}), 3.53(\mathrm{t}, J=4.8 \mathrm{~Hz}, 2 \mathrm{H}), 3.51(\mathrm{~s}, 2 \mathrm{H}), 2.53$ (t, $J=4.8 \mathrm{~Hz}, 2 \mathrm{H}), 2.48$ (t, $J$ $=4.8 \mathrm{~Hz}, 2 \mathrm{H})$. HRESIMS calcd for $\mathrm{C}_{15} \mathrm{H}_{17} \mathrm{Cl}_{2} \mathrm{~N}_{6} \mathrm{O}_{3} \mathrm{~m} / \mathrm{z}[\mathrm{M}+\mathrm{H}]^{+} 399.0734,401.0707$ found 399.0738, 401.0710.

4.1.3.12. 1-(4-((4-Chlorophenyl)(phenyl)methyl)piperazin-1-yl)-2-(3-nitro-1H-1,2,4-triazol-1-yl) ethanone (13): Off white microcrystals (84 \%): $\mathrm{mp} 94-96{ }^{\circ} \mathrm{C} ;{ }^{1} \mathrm{H}$ NMR $\left(400 \mathrm{MHz},\left(\mathrm{CD}_{3} \mathrm{Cl}\right) \delta\right.$ : 8.34 (s, 1H), 7.37-7.23 (m, 9H), 5.13 (s, 2H), 4.27 (s, 1H), 3.65 (br t, J = 5.0 Hz, 2H), 3.50 (br t, $J=5.0 \mathrm{~Hz}, 2 \mathrm{H}$ ), 2.47 (br t, $J=5.0 \mathrm{~Hz}, 2 \mathrm{H}), 2.42(\mathrm{t}, J=5.0 \mathrm{~Hz}, 2 \mathrm{H})$. HRESIMS calcd for $\mathrm{C}_{21} \mathrm{H}_{22} \mathrm{ClN}_{6} \mathrm{O}_{3}$ and $\mathrm{C}_{21} \mathrm{H}_{21} \mathrm{ClN}_{6} \mathrm{NaO}_{3} \mathrm{~m} / \mathrm{z}[\mathrm{M}+\mathrm{H}]^{+}$and $[\mathrm{M}+\mathrm{Na}]^{+}$441.1436, 443.1416 and 463.1256, 465.1235 found 441.1436, 443.1425 and 463.1254, 465.1233.

4.1.3.13. 1-(4-(Cyclopropanecarbonyl)piperazin-1-yl)-2-(3-nitro-1H-1,2,4-triazol-1-yl)ethanone (14): White crystals (84 \%): mp 63-65 ${ }^{\circ} \mathrm{C} ;{ }^{1} \mathrm{H}$ NMR (400 MHz, $\left(\mathrm{CD}_{3} \mathrm{COCD}_{3}\right) \delta$ : 8.59 (s, $\left.1 \mathrm{H}\right)$, 
5.57 (s, 2H), 3.80-3.50 (br m, 8H), $1.96(\mathrm{~m}, 1 \mathrm{H}), 0.85-0.81$ (m, 2H), 0.76-0.71 (m, 2H). HRESIMS calcd for $\mathrm{C}_{12} \mathrm{H}_{16} \mathrm{~N}_{6} \mathrm{NaO}_{4} \mathrm{~m} / \mathrm{z}[\mathrm{M}+\mathrm{Na}]^{+}$331.1125, found 331.1126.

4.1.3.14. 1,2-bis(4-(4-chlorophenyl)piperazin-1-yl)ethanone (15): Off white powder (44\%): mp 165-167 ${ }^{\circ} \mathrm{C} ;{ }^{1} \mathrm{H}$ NMR $\left(400 \mathrm{MHz},\left(\mathrm{CD}_{3} \mathrm{Cl}\right) \delta: 7.23(\mathrm{~d}, J=9.2 \mathrm{~Hz}, 2 \mathrm{H}), 7.21(\mathrm{~d}, J=9.2 \mathrm{~Hz}, 2 \mathrm{H})\right.$, 6.85 (d, $J=9.2 \mathrm{~Hz}, 2 \mathrm{H}), 6.83$ (d, $J=9.2 \mathrm{~Hz}, 2 \mathrm{H}), 3.79$ (t, $J=4.8 \mathrm{~Hz}, 4 \mathrm{H}), 3.30$ (s, 2H), 3.183,12 (m, 8H), 2.69 (t, $J=4.8 \mathrm{~Hz}, 4 \mathrm{H})$. HRESIMS calcd for $\mathrm{C}_{22} \mathrm{H}_{27} \mathrm{Cl}_{2} \mathrm{~N}_{4} \mathrm{O} \mathrm{m} / \mathrm{z}[\mathrm{M}+\mathrm{H}]^{+}$ 433.1556, 435.1531 found 433.1560, 435.1535.

4.1.3.15. 1,2-bis(4-(3,4-dichlorophenyl)piperazin-1-yl)ethanone (16): Off white powder (33\%): mp 79-81 ${ }^{\circ} \mathrm{C} ;{ }^{1} \mathrm{H}$ NMR $\left(400 \mathrm{MHz},\left(\mathrm{CD}_{3} \mathrm{Cl}\right) \delta: 7.29(\mathrm{~d}, J=9.2 \mathrm{~Hz}, 1 \mathrm{H}), 7.28(\mathrm{~d}, J=9.2 \mathrm{~Hz}, 1 \mathrm{H})\right.$, $6.96(\mathrm{~d}, J=2.8 \mathrm{~Hz}, 1 \mathrm{H}), 6.95(\mathrm{~d}, J=2.8 \mathrm{~Hz}, 1 \mathrm{H}), 6.76-6.72(\mathrm{~m}, 2 \mathrm{H}), 3.77(\mathrm{t}, J=5.2 \mathrm{~Hz}, 4 \mathrm{H})$, 3.29 (s, 2H), 3.18-3.14 (m, 8H), 2.67 (t, $J=5.2,4 \mathrm{H})$. HRESIMS calcd for $\mathrm{C}_{22} \mathrm{H}_{25} \mathrm{Cl}_{4} \mathrm{~N}_{4} \mathrm{O} \mathrm{m} / \mathrm{z}$ $[\mathrm{M}+\mathrm{H}]^{+}$501.0777, 503.0750 found 501.0788, 503.0761.

4.1.3.16. 1,2-bis(4-(4-(trifluoromethyl)phenyl)piperazin-1-yl)ethanone (17): Off white powder (49\%): mp 150-152 ${ }^{\circ} \mathrm{C} ;{ }^{1} \mathrm{H}$ NMR (400 MHz, $\left(\mathrm{CD}_{3} \mathrm{Cl}\right) \delta$ : 7.51 (d, $\left.J=8.8 \mathrm{~Hz}, 2 \mathrm{H}\right), 7.48$ (d, $J=8.8$ Hz, 2H), 6.93 (d, $J=8.8 \mathrm{~Hz}, 2 \mathrm{H}), 6.91$ (d, $J=8.8 \mathrm{~Hz}, 2 \mathrm{H}), 3.80$ (t, $J=4.8 \mathrm{~Hz}, 4 \mathrm{H}), 3.30$ (m, $10 \mathrm{H}$ ), $2.70\left(\mathrm{t}, J=4.8 \mathrm{~Hz}, 4 \mathrm{H}\right.$ ). HRESIMS calcd for $\mathrm{C}_{24} \mathrm{H}_{27} \mathrm{~F}_{6} \mathrm{~N}_{4} \mathrm{O} \mathrm{m} / \mathrm{z}[\mathrm{M}+\mathrm{H}]^{+}$501.2084, 502.2114 found 501.2094, 502.2123. 
4.1.3.17. 1,2-bis(4-(p-tolyl)piperazin-1-yl)ethanone (18): Off white powder (37\%): mp 149-151 ${ }^{\circ} \mathrm{C} ;{ }^{1} \mathrm{H}$ NMR (400 MHz, $\left(\mathrm{CD}_{3} \mathrm{Cl}\right) \delta: 7.09(\mathrm{~d}, J=8.8 \mathrm{~Hz}, 2 \mathrm{H}), 7.07$ (d, $\left.J=8.8 \mathrm{~Hz}, 2 \mathrm{H}\right), 6.84(\mathrm{~d}, J$ $=8.8 \mathrm{~Hz}, 2 \mathrm{H}), 6.83(\mathrm{~d}, J=8.8 \mathrm{~Hz}, 2 \mathrm{H}), 3.78(\mathrm{~m}, 4 \mathrm{H}), 3.28(\mathrm{~s}, 2 \mathrm{H}), 3.14(\mathrm{~m}, 8 \mathrm{H}), 2.69(\mathrm{t}, J=4.8$ $\mathrm{Hz}, 4 \mathrm{H}), 2.28(\mathrm{~s}, 3 \mathrm{H}), 2.27$ (s, 3H). HRESIMS calcd for $\mathrm{C}_{24} \mathrm{H}_{33} \mathrm{~N}_{4} \mathrm{O} \mathrm{m} / \mathrm{z}[\mathrm{M}+\mathrm{H}]^{+} 393.2649$, 394.2680 found 393.2659, 394.2688.

4.1.3.18. 1,2-bis(4-(2-cyanophenyl)piperazin-1-yl)ethanone (19): Off white powder (55\%): mp 115-117 ${ }^{\circ} \mathrm{C} ;{ }^{1} \mathrm{H}$ NMR (400 MHz, $\left(\mathrm{CD}_{3} \mathrm{Cl}\right) \delta: 7.62-7.47(\mathrm{~m}, 4 \mathrm{H}), 7.10-7.00(\mathrm{~m}, 4 \mathrm{H}), 3.86(\mathrm{t}, J=$ $4.8 \mathrm{~Hz}, 4 \mathrm{H}), 3.33(\mathrm{~s}, 2 \mathrm{H}), 3.27-3.16(\mathrm{~m}, 8 \mathrm{H}), 2.77(\mathrm{t}, J=4.8 \mathrm{~Hz}, 4 \mathrm{H})$. HRESIMS calcd for $\mathrm{C}_{24} \mathrm{H}_{27} \mathrm{~N}_{6} \mathrm{O} m / \mathrm{z}[\mathrm{M}+\mathrm{H}]^{+} 415.2241$ found 415.2239 .

\subsection{Biological evaluation.}

\subsubsection{In vitro screening:}

In vitro activity against $T$. cruzi, T. b. rhodesiense, L. donovani and cytotoxicity assessment using L6 cells (rat skeletal myoblasts) was determined using a 96-well plate format as previously described [37]. Data were analyzed with the graphic program Softmax Pro (Molecular Devices, Sunnyvale, CA, USA), which calculated $\mathrm{IC}_{50}$ values by linear regression from the sigmoidal dose inhibition curves.

\subsubsection{In vitro T. brucei brucei antiproliferating assays and susceptibility studies.}

T. brucei brucei bloodstream form parasites were seeded at $1 \times 10^{3} \mathrm{~mL}^{-1}$ in $200 \mu \mathrm{L}$ of growth medium containing different concentrations of a nitrotriazole or nifurtimox. Where appropriate, induction of the TbNTR was carried out by adding tetracycline $(1 \mu \mathrm{g} / \mathrm{mL})$. After incubation for 3 days at $37^{\circ} \mathrm{C}, 20 \mu \mathrm{L}$ of Alamar blue was added to each well and the plates incubated for a further $16 \mathrm{~h}$. The cell density of each culture was determined as described before [24] and the $\mathrm{IC}_{50}$ established. 


\subsubsection{Enzymatic activity studies with Type I NTRs.}

Recombinant TbNTR and TcNTR were prepared and assayed as previously described [38, 39]. The activity of purified his-tagged TbNTR was assessed spectrophotometrically at $340 \mathrm{~nm}$ using various nitrotriazole substrates $(100 \mu \mathrm{M})$ and NADH $(100 \mu \mathrm{M})$ and expressed as nmol NADH oxidized $\mathrm{min}^{-1} \mathrm{mg}^{-}$ ${ }^{1}$ of enzyme.

\subsubsection{ADMET studies}

4.2.4.1. Caco-2 permeability assay was performed as described before [40]. For Apical to Basolateral (A>B) permeability, the compound was added to the apical (A) side and amount of permeation was determined on the basolateral (B) side; for Basolateral to Apical (B->A) permeability, the compound was added to the B side and the amount of permeation was determined on the A side. Assays were run for $2 \mathrm{~h}$ in duplicate and the amount of compound present in each compartment was quantified by LC-MS/MS. Control compounds for low and high permeability were included in each experiment as well as the P-gp efflux control, talinolol [41].

4.2.4.2. Inhibition of CYP P450 isoforms was assessed by using CYP2B6, CYP2C8, CYP2C9, CYP2C19, CYP2D6 and CYP3A4. For each assay, human liver microsomes were incubated at $37{ }^{\circ} \mathrm{C}$ with a probe substrate for each CYP isoform in the presence of a compound at various concentrations (up to $20 \mu \mathrm{M}$ ) for $5 \mathrm{~min}$ (except CYP2C19 for $35 \mathrm{~min}$ ). The formation of metabolites for each isoform was quantified by LC-MS/MS as a measure of enzyme activity and an $\mathrm{IC}_{50}$ value (the compound concentration which produces 50\% inhibition) was generated [42].

4.2.4.3. Microsomal stability. Compounds were tested for microsomal stability by using pooled human liver S9 microsomes $(0.3 \mathrm{mg} / \mathrm{mL})$, which were incubated with test compound at $37^{\circ} \mathrm{C}$ in the presence or absence of the co-factor NADPH. The reaction was terminated, the supernatant recovered and test 
compound quantified by LC-MS/MS. A fixed compound-concentration was tested in duplicate at 5 timepoints and compound stability expressed as a function of time [43].

\subsubsection{In vivo antichagasic activity assessment of compound 3:}

The study was performed as described before [20, 22]. Briefly, trypomastigote forms from transgenic T. cruzi Y strain expressing firefly luciferase were injected in Balb/c mice $\left(10^{5}\right.$ trypomastigotes per mouse) and three days later mice were anesthetized by inhalation of isofluorane, followed by an injection with $150 \mathrm{mg} / \mathrm{kg}$ of D-luciferin potassium-salt in PBS. Mice were imaged 5 to 10 min after injection of luciferin with an IVIS 100 (Xenogen, Alameda, CA) and the data acquisition and analysis were performed with the software LivingImage (Xenogen) as described before [44]. Treatment with test compound or bnz was started 4 days after infection at $15 \mathrm{mg} / \mathrm{kg} /$ day x 10 days, given i.p. The vehicle control was $2 \%$ methylcellulose $+0.5 \%$ Tween 80 and groups of 5 mice/group were used. Mice were imaged after a 10-day treatment. The ratio of parasite levels was calculated for each animal dividing the luciferase signal after treatment by the luciferase signal on the first imaging (before treatment). Mean values of all animals in each group \pm SD were used for plotting.

\section{Acknowledgements:}

The authors thank M. Cal, M. Jud and S. Keller (Swiss TPH) for parasite assay results and Dr. Ana Rodriguez (New York University School of Medicine) for obtaining the in vivo data. This work was supported in part: a) by internal funds of the Radiation Medicine Department at NorthShore University HealthSystem; b) the National Institutes of Health and the National Institute of Allergy and Infectious Diseases, Contract No. HHSN272201100009I (ADMET studies). In addition, the Drugs for Neglected Diseases initiative (DNDi) received financial 
support from the Bill \& Melinda Gates Foundation (BMGF) to perform the in vitro screenings against parasites. The donors had no role in study design, data collection and analysis, decision to publish, or preparation of the manuscript.

\section{References}

[1] http://www.who.int/tdr.

[2] K. Stuart, R. Brun, S. Croft, A. Fairlamb, R.E. Gürtler, J. McKerrow, S. Reed, R. Tarleton, Kinetoplastids: related protozoan pathogens, different diseases, J. Clin. Invest. 118 (2008) $1301-1310$.

[3] DNDi-website available: http://www.dndi.org/diseases-projects/diseases/chagas/currenttreatment.html

[4] J.A. Castro, M. Montalto de Mecca, L.C. Bartel, Toxic side effects of drugs used to treat Chagas’ disease (American trypanosomiasis), Human \& Exper. Toxicol. 25 (2006) 471479.

[5] S. Sundar, A. Singh, M. Rai, V.K. Prajapati, A.K. Singh, B. Ostyn, M. Boelaert, J-C. Dujardin, J. Chakravarty, Efficacy of miltefosine in the treatment of visceral leishmaniasis in India after a decade of use, Clin. Infect. Dis., 55(4) (2012) 543-550

[6] G.A.S. Romero, M. Boelaert, Control of visceral leishmaniasis in Latin America - a $\begin{array}{lllllll}\text { systematic review, } & \text { PLoS Negl. Trop. Dis. 4(1) (2010) e584 }\end{array}$ http://dx.doi.org/10.1371/journal.pntd.0000584

[7] L. Van Griensven, M. Balasegaram, F. Meheus, J. Alvar, L. Lynen, M. Boelaert, Combination therapy for visceral leishmaniasis, Lancet. Infect. Dis. 10 (2010) 184-194. 
[8] J.A. Urbina, Ergosterol biosynthesis and drug development for Chagas disease, Mem. Inst. Oswaldo Cruz 104(Suppl1) (2009) 311-318.

[9] M. Keenan, M.J. Abbott, P.W. Alexander, T. Armstrong, W.M. Best, B. Berven, A. Botero, J.H. Chaplin, S.A. Charman, E. Chatelain, T.W. von Geldern, M. Kerfoot, A. Khong, T. Nguyen, J.D. McManus, J. Morizzi, E. Ryan, I. Scandale, R.A. Thompson, S.Z. Wang, K.L. White, Analogues of fenarimol are potent inhibitors of Trypanosomal cruzi and are efficacious in a murine model of Chagas disease, J. Med. Chem. 55 (2012) 41894204.

[10] G.I. Lepesheva, R.D. Ott, T.Y. Hargrove, Y.Y. Kleshchenko, I. Schuster, W.D. Nes, G.C. Hill, F. Villalta, M.R. Waterman, Sterol 14alpha-demethylase as a potential target for antitrypanosomal therapy: enzyme inhibition and parasite cell growth, Chem. Biol. 14 (2007) 1283-1293.

[11] T.Y. Hargrove, K. Kim, M.D.C. Soeiro, C.F. da Silva, D.D.J. Batista, M.M. Batista, E.M. Yazlovitskaya, M.R. Waterman, G.A. Sulikowski, G.I. Lepesheva, Cyp51 structures and structure-based development of novel, pathogen-specific inhibitory scaffolds, Int. J. Parasitol. Drugs Drug Resist. 2 (2012) 178-186.

[12] F. Villalta, M.C. Dobish, P.N. Nde, Y.Y. Kleshchenko, T.Y. Hargrove, C.A. Johnson, M.R. Waterman, J.N. Johnston, G.I. Lepesheva, VNI Cures Acute and Chronic Experimental Chagas Disease, J. Infect. Dis. 208 (2013) 504-511.

[13] G. Andriani, E. Amata, J. Beatty, Z. Clements, B.J. Coffey, G. Courtemanche, W. Devine, J. Erath, C.E. Juda, Z. Wawrzak, J.T. Wood, G.I. Lepesheva, A. Rodriguez, M.P. Pollastri, Antitrypanosomal lead discovery: Identification of a ligand-efficient inhibitor of Trypanosoma cruzi CYP51 and parasite growth, J. Med. Chem. 56 (2013) 2556-2567. 
[14] I. Molina, J.G. Prat, F. Salvador, B. Treviño, E. Sulleiro, N. Serre, D. Pou, S. Roure, J. Cabezos, L. Valerio, A. Blanco-Grau, A. Sánchez-Montalvá, X. Vidal, A. Pahissa, Randomized trial of posaconazole and benznidazole for chronic Chagas’ disease, N. Engl. J. Med. 370 (2014) 1899-1907.

[15] C.B. Moraes, M.A. Giardini, H. Kim, C.H. Franco, A.M. Araujo-Junior, S. Schenkman, E. Chatelain, L.H. Freitas-Junior, Nitroheterocyclic compounds are more efficacious than CYP51 inhibitors against Trypanosoma cruzi: implications for Chagas disease drug discovery and development, Scientific Reports 4 (2014) 4703-4714.

[16] L.d.F. Diniz, J.A. Urbina, I.M. de Andrade, A.L. Mazzeti, T.A.F. Martins, I.S. Caldas, A. Talvani, I. Ribeiro, M.T. Bahia, Benznidazole and posaconazole in experimental Chagas disease: Positive interaction in concomitant and sequential treatments, PLoS Negl. Trop. Dis. 7 (2013) e2367. doi:10.1371/journal.pntd.0002367.

[17] M.V. Papadopoulou, B. Bourdin Trunz, W.D. Bloomer, C. McKenzie, S.R. Wilkinson, C. Prasittichai, R. Brun, M. Kaiser, E. Torreele, Novel 3-nitro-1H-1,2,4-triazole-based aliphatic and aromatic amines as anti-Chagasic agents, J. Med. Chem. 54 (2011) 82148223.

[18] M.V. Papadopoulou, W.D. Bloomer, H.S. Rosenzweig, E. Chatelain, M. Kaiser, S.R. Wilkinson, C. McKenzie, J-R. Ioset, Novel 3-nitro-1H-1,2,4-triazole-based amides and sulfonamides as potential anti-trypanosomal agents, J. Med. Chem. 55 (2012) 5554-5565.

[19] M.V. Papadopoulou, W.D. Bloomer, H.S. Rosenzweig, M. Kaiser, E. Chatelain, J-R. Ioset, Novel 3-nitro-1H-1,2,4-triazole-bearing piperazines and 2-amino-benzothiazoles as antiChagasic agents, Bioorg. Med. Chem. 21 (2013) 6600-6607. 
[20] M.V. Papadopoulou, W.D. Bloomer, H.S. Rosenzweig, R. Ashworth, S.R. Wilkinson, M. Kaiser, G. Andriani, A. Rodriguez, Novel 3-nitro-1H-1,2,4-triazole-based compounds as potential anti-Chagasic drugs: In vivo studies, Future Med. Chem. 5 (2013) 1763-1776.

[21] M.V. Papadopoulou, W.D. Bloomer, H.S. Rosenzweig, S.R. Wilkinson, M. Kaiser, Novel nitro(triazole/imidazole)-based heteroarylamides/ sulfonamides as potential antitrypanosomal agents, Eur. J. Med. Chem. 87 (2014) 79-88.

[22] M.V. Papadopoulou, W.D. Bloomer, G.I. Lepesheva, H.S. Rosenzweig, M. Kaiser, B. Aguilera-Venegas, S.R. Wilkinson, E. Chatelain, J-R. Ioset, Novel 3-nitrotriazole-based amides and carbinols as bifunctional anti-Chagasic agents, J. Med. Chem. 58 (2015) 13071319.

[23] G. Buchanan-Kilbey, J. Djumpah, M.V. Papadopoulou, W.D. Bloomer, L. Hu, S.R. Wilkinson, R. Ashworth, Evaluating the developmental toxicity of trypanocidal nitroaromatic compounds on zebrafish, Acta Tropica 128 (2013) 701-705.

[24] S.R. Wilkinson, M.C. Taylor, D. Horn, J.M. Kelly, Cheeseman, I. A mechanism for crossresistance to nifurtimox and benznidazole in trypanosomes, PNAS 105 (2008) 5022-5027.

[25] S. Alsford, S. Eckert, N. Baker, L. Glover, A. Sanchez-Flores, K.F. Leung, D.J. Turner, M.C. Field, M. Berriman, D. Horn, High-throughput decoding of antitrypanosomal drug efficacy and resistance, Nature 482 (2010) 232-236.

[26] N. Baker, S. Alsford, D. Horn, Genome-wide RNAi screens in African trypanosomes identify the nifurtimox activator NTR and the eflornithine transporter AAT6, Mol. Biochem. Parasitol. 176 (2011) 55-57. 
[27] S.R. Wilkinson, C. Bot, J.M. Kelly, B.S. Hall, Trypanocidal activity of nitroaromatic prodrugs: current treatments and future perspectives, Curr. Top. Med. Chem. 11 (2011) 2072-2084.

[28] S. Nwaka, B. Ramirez, R. Brun, L. Maes, F. Douglas, R. Ridley, Advancing drug innovation for neglected diseases—criteria for lead progression, PLoS Negl. Trop. Dis. 3 (2009) e440. doi:10.1371/journal.pntd.0000440.

[29] A. Kamal, G. Ramakrishna, P. Raju, A.V. Subba Rao, J. Joseph, B. Siddhardha, U.S.N. Murty, Synthesis of cinnamamide dimers as potential antibacterial and antifungal agents, Let. In Drug Design \& Discovery, 8 (2011) 957-965.

[30] L.L. Gan, B. Fang, C-H. Zhou, Synthesis of azole-containing piperazine derivatives and evaluation of their antibacterial, antifungal and cytotoxic activities, Bull. Korean Chem. Soc. 31(12) (2010) 3684-3692 (Eng).

[31] M.A. Al-Qtaitat, H.A. Saadeh, A.G. Al-Bakri, H. Kaur, K. Goyal, R. Sehgal, M.S. Mubarak, Synthesis, characterization, and biological activity of novel metronidazolepiperazine amides, Monatshefte fuer Chemie/Chemical Monthly 146(4) (2014), DOI: 10.1007/s00706-014-1352-0

[32] R. Yendapally, R.P. Tangallapally, R.E.B. Lee, R.E. Lee, Design, synthesis, and biological evaluation of nitrofuranyl amides, diamides and amines with enhanced activity against Mycobacterium tuberculosis, 229th ACS National Meeting, San Diego, CA, US (2005) MEDI-376.

[33] C. Sanjeevarayappa, P. Iyengar, T. Sumana, K.E. Manoj Kumar, H.K. Prathap, Design, synthesis, characterization and biological evaluation of novel amides containing 1,2,4oxadiazole derivatives, J. Applicable Chem. 3(1) (2014) 38-46. 
[34] K.S. Ly, M.A. Letavic, J.M. Keith, J.M. Miller, E.M. Stocking, A.J. Barbier, P. Bonaventure, B. Lord, X. Jiang, J.D. Boggs, L. Dvorak, K.L. Miller, D. Nepomuceno, S.J. Wilson, N.I. Carruthers, Synthesis and biological activity of piperazine and diazepane amides that are histamine $\mathrm{H}_{3}$ antagonists and serotonin reuptake inhibitors, Bioorg. \& Med. Chem. Let. 18 (2008) 39-43.

[35] A. Bischoff, H. Subramanya, K. Sundaresan, S.R. Sammeta, A.K. Vaka, Preparation of piperazine derivatives as inhibitors of stearoyl-CoA desaturase, U.S. Pat. Appl. Publ. (2010) US 20100160323 A1 20100624 (Eng).

[36] H. Yamaguchi, K. Maruta, R. Nagata, K. Ushiroda, K. Iwai, Diabetic remedy containing dipiperazine derivatives, PCT Appl. (2001) WO2001036386 A 20010525 (Japanese).

[37] I. Orhan, B. Sener, M. Kaiser, R. Brun, R.; D. Tasdemir, Inhibitory activity of marine sponge-derived natural products against parasitic protozoa, Mar. Drugs 8 (2010) 47-58.

[38] B.S. Hall, X. Wu, L. Hu, S.R. Wilkinson, Exploiting the drug-activating properties of a novel trypanosomal nitroreductase, Antimicrob. Agents Chemother. 54 (2010) 1193-1199.

[39] B.S. Hall, E.L. Meredith, S.R. Wilkinson, Targeting the substrate preference of a type I nitroreductase to develop anti-trypanosomal quinone-based prodrugs, Antimicrob. Agents Chemother. 56 (2012) 5821-5830.

[40] P. Artursson, K. Palm, K. Luthman, Caco-2 monolayers in experimental and theoretical predictions of drug transport, Adv. Drug Deliv. Rev. 46 (2001) 27-43.

[41] C.J. Endres, P. Hsiao, F.S. Chung, J.D. Unadkat, The role of transporters in drug interactions, Eur. J. Pharm. Sci. 27 (2006) 501-517.

[42] M.J. Kim, H. Kim, I.J. Cha, J.H. Shon, K.H. Liu, J.G. Shin, High-throughput screening of inhibitory potential of nine cytochrome P450 enzymes in vitro using liquid 
chromatography/tandem mass spectrometry, Rapid Commun. Mass Spectrom. 19 (2005) 2651-2658.

[43] R.S. Obach, Prediction of human clearance of twenty-nine drugs from hepatic microsomal intrinsic clearance data: an examination of in vitro half-life approach and non-specific binding to microsomes, Drug Metab. Dispos. 27 (1999) 1350-1359.

[44] G. Andriani, A-D.C. Chessler, G. Courtemanche, B.A. Burleigh, A. Rodriguez, Activity in vivo of anti-trypanosoma cruzi compounds selected from a high throughput screening, PLoS Negl. Trop. Dis. 5 (2011) e1298.

\section{Captions:}

Fig. 1. Correlation graph between lipophilicity and antichagasic activity in the 3-nitrotriazolebased arylpiperazides. Compounds 2-9 and 11-13 were used.

Fig. 2. In vivo evaluation of the antichagasic efficacy of compound $\mathbf{3}$ and benznidazole (Bnz) in an acute murine model. Compounds were administered (i.p.) at $15 \mathrm{mg} / \mathrm{kg} /$ day for 10 consecutive days. Parasite ratios were calculated on day 10. Groups of 5 mice/group were used. 


\section{Graphical Abstract}

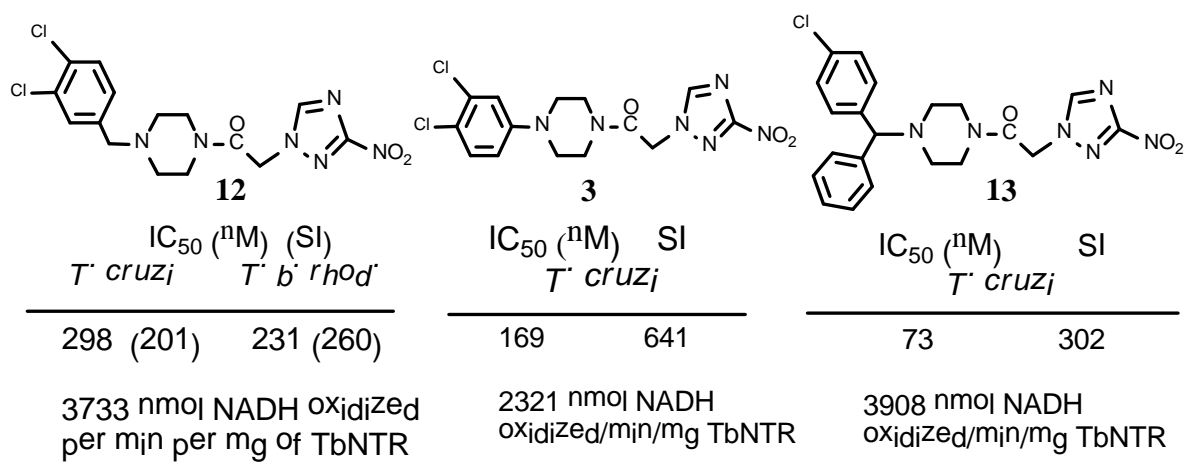


Table 1. In vitro antiparasitic activity, host toxicity and physical properties of tested compounds.

\begin{tabular}{|c|c|c|c|c|c|c|c|c|c|c|c|}
\hline & T.b.rhod. $^{\alpha}$ & SI & T. cruzi ${ }^{b}$ & SI & L.don. axen. ${ }^{c}$ & $S I^{d}$ & Cytotox. $L 6^{\mathrm{e}}$ & Chemical & $\mathrm{Bnz} /$ comp & clogP & PSA $\left(\AA^{2}\right)$ \\
\hline ID No & $\mathrm{IC}_{50} \mu \mathrm{M}$ & & $\mathrm{IC}_{50} \mu \mathrm{M}$ & & $\mathrm{IC}_{50} \mu \mathrm{M}$ & & $\mathrm{IC}_{50} \mu \mathrm{M}$ & Structure & & & \\
\hline Melar. & $0.009 \pm 0.001$ & & & & & & & & & & \\
\hline $\mathrm{Bnz}$ & & & $2.153 \pm 0.176$ & & & & & & & & \\
\hline Milt. & & & & & $0.162 \pm 0.017$ & & & & & & \\
\hline 2 & 74.32 & $>4$ & 1.124 & $>254$ & 9.386 & $>30$ & $>285.3$ & & 1.8 & 1.634 & 103.32 \\
\hline 3 & 4.478 & 24 & 0.169 & 641 & 1.223 & 89 & 108.4 & & 12 & 2.287 & 103.32 \\
\hline 4 & 4.219 & 48 & 0.596 & 340 & 1.878 & 108 & 202.47 & & 3.4 & 1.932 & 103.32 \\
\hline 5 & 9.909 & 15 & 1.33 & 112 & 10.758 & 14 & 148.48 & & 1.52 & 1.249 & 103.32 \\
\hline 6 & 16.36 & 8.1 & 2.42 & 54.67 & 18.47 & 7.18 & 132.57 & & 0.94 & 0.773 & 112.55 \\
\hline 7 & 11.26 & 19 & 2.85 & 75 & 14.575 & 15 & 213.05 & & 0.71 & 0.58 & 127.11 \\
\hline 8 & 19.27 & 8.98 & 4.64 & 37.32 & 18.52 & 9.35 & 173.1 & & 0.49 & -0.198 & 115.68 \\
\hline 9 & 33.4 & 4.5 & 10 & 15 & 22.95 & 6.52 & 149.69 & & 0.23 & -0.963 & 128.04 \\
\hline 10 & 156.62 & 1.79 & 141.83 & 1.97 & 132.87 & 2.11 & 279.97 & & 0.02 & -0.152 & 115.68 \\
\hline 11 & 1.39 & 79.3 & 0.862 & 128.4 & 9.7 & 11.4 & 110.63 & & 2.64 & 1.924 & 103.32 \\
\hline 12 & 0.231 & 260 & 0.298 & 200.7 & 8.13 & 7.36 & 59.85 & & 7.64 & 2.347 & 103.32 \\
\hline 13 & 3.41 & 6.43 & 0.073 & 301.6 & 1.45 & 14.55 & 21.91 & & 31.19 & 3.102 & 103.32 \\
\hline 14 & 85.16 & 1.83 & 148.18 & 1.05 & 30.58 & 5.12 & 156.49 & & 0.01 & -1.077 & 120.39 \\
\hline
\end{tabular}


Table 1. (continuation).

\begin{tabular}{|c|c|c|c|c|c|c|c|c|c|c|c|}
\hline & T.b.rhod. ${ }^{a}$ & $\mathrm{SI}$ & T. cruzi $i^{b}$ & $\mathrm{SI}$ & L.don. axen. ${ }^{c}$ & $\mathrm{Sl}^{\mathrm{d}}$ & Cytotox. $\mathrm{L}^{\mathrm{e}}$ & Chemical & $\mathrm{Bnz} /$ comp & $c \log P$ & $\operatorname{PSA}\left(\AA^{2}\right)$ \\
\hline ID No & $\mathrm{IC}_{50} \mu \mathrm{M}$ & & $\mathrm{IC}_{50} \mu \mathrm{M}$ & & $\mathrm{IC}_{50} \mu \mathrm{M}$ & & $\mathrm{IC}_{50} \mu \mathrm{M}$ & Structure & & & \\
\hline 15 & 12.61 & 9 & 6.062 & 19 & 18.048 & 6 & 116.28 & & 0.33 & 5.674 & 30.03 \\
\hline 16 & 25.996 & $<1$ & 1.811 & 11 & 6.265 & 3 & 20.19 & & 1.12 & 6.979 & 30.03 \\
\hline 17 & 24.6 & 1.2 & 2.71 & 12 & 5.03 & 6 & 31.74 & & 0.75 & 6.27 & 30.03 \\
\hline 18 & 26.3 & 8.1 & 29.847 & 7 & 24.247 & 9 & 212.76 & & 0.07 & 4.904 & 30.03 \\
\hline 19 & 12.79 & 9.9 & 25.72 & 5 & 24.3 & 4 & 126.93 & & 0.08 & 3.63 & 77.61 \\
\hline
\end{tabular}

${ }^{\mathrm{a}}$ T.b. rhodesiense, strain STIB 900 BSF trypomastigotes; ${ }^{\mathrm{b}}$ T. cruzi, strain Tulahuen C4 amastigotes; ${ }^{\mathrm{c}}$ L. donovani axenic, strain MHOM-ET-67/L82 amastigotes; ${ }^{\mathrm{d}}$ Selectivity index (SI) is the ratio: $\mathrm{IC}_{50}$ in $\mathrm{L} 6$ cells/ $\mathrm{IC}_{50}$ in each parasite. ${ }^{\mathrm{e}}$ Cytotoxicity in the host $\mathrm{L} 6$ cells. Reference drugs: Melarsoprol (Melar.), Benznidazole (Bnz), Miltefosine (Milt.). The $\mathrm{IC}_{50}$ value of each reference drug is the mean from multiple measurements in parallel with the compounds of interest. Active and moderately active compounds with acceptable selectivity are colored green and light green, respectively; active/moderately active compounds with an unacceptable selectivity are colored blue whereas inactive compounds are colorless. PSA: polar surface area. All physical properties were predicted by using the Marvin Calculator (www.chemaxon.com). $\mathrm{IC}_{50}$ values are means of 2 to 3 measurements. The $\mathrm{SD}$ was $<5 \%$. 
Table 2. Activity of recombinant TbNTR and TcNTR towards selected analogs of Table 1 .

\begin{tabular}{|c|cc|}
\hline & \multicolumn{2}{c|}{$\begin{array}{c}\text { Specific activity } \\
\text { (nmol of NADH oxidized per min } \\
\text { per mg of NTR) }\end{array}$} \\
\hline $\mathbf{2}$ & TbNTR & TcNTR \\
\hline $\mathbf{3}$ & $2185 \pm 46$ & $761 \pm 39$ \\
\hline $\mathbf{4}$ & $2321 \pm 72$ & $753 \pm 88$ \\
\hline $\mathbf{5}$ & $2194 \pm 34$ & $707 \pm 53$ \\
\hline $\mathbf{9}$ & $2065 \pm 19$ & $787 \pm 35$ \\
\hline $\mathbf{1 1}$ & $3800 \pm 51$ & $743 \pm 51$ \\
\hline $\mathbf{1 2}$ & $3733 \pm 49$ & $701 \pm 22$ \\
\hline $\mathbf{1 3}$ & $3908 \pm 62$ & $745 \pm 102$ \\
\hline Bnz & $1540 \pm 5$ & $672 \pm 87$ \\
\hline
\end{tabular}


Table 3. Antimicrobial activity of selected 3-nitrotriazole-based piperazides against wild type and TbNTR overexpressing T. b. brucei parasites.

\begin{tabular}{|c|c|c|c|c|}
\hline \multirow[t]{2}{*}{ Compound } & \multicolumn{3}{|c|}{ IC50 value ( $\mu \mathrm{M})$ against $T . b$. brucei } & \multirow{2}{*}{$\begin{array}{r}\text { Ratio } \\
\text {-tet/+tet }\end{array}$} \\
\hline & wild type & TbNTR (-tet) & TbNTR (+tet) & \\
\hline $\mathbf{n f x}$ & & $4.41 \pm 0.22$ & $0.43 \pm 0.03$ & 10.3 \\
\hline 2 & $>30.00$ & & & \\
\hline 3 & $4.73 \pm 0.44$ & $7.97 \pm 0.70$ & $0.65 \pm 0.04$ & 12.3 \\
\hline 4 & $17.53 \pm 1.92$ & $13.62 \pm 0.65$ & $0.85 \pm 0.06$ & 16 \\
\hline 5 & $>30.00$ & & & \\
\hline 9 & $>30.00$ & & & \\
\hline 11 & $26.01 \pm 1.94$ & $>30$ & $1.78 \pm 0.24$ & $>16.9$ \\
\hline 12 & $3.59 \pm 0.12$ & $4.13 \pm 0.38$ & $0.58 \pm 0.03$ & 7.2 \\
\hline 13 & $2.75 \pm 0.12$ & $3.86 \pm 0.23$ & $1.04 \pm 0.04$ & 3.7 \\
\hline
\end{tabular}


Table 4. Microsomal (human) stability data summary

\begin{tabular}{|ccccc|}
\hline Compound & \multicolumn{2}{c|}{$\mathbf{C l}_{\mathbf{i n t}}{ }^{\mathbf{a}}$} & \multicolumn{2}{c|}{$\mathbf{T}_{\mathbf{1} / \mathbf{2}}{ }^{\mathbf{b}}(\mathbf{m i n})$} \\
$(\mathbf{1} \boldsymbol{\mu M})$ & $(+) \mathbf{N A D P H}$ & $(-) \mathbf{N A D P H}$ & $(+) \mathbf{N A D P H}$ & $(-) \mathbf{N A D P H}$ \\
\hline Verapamil & 114 & 12.8 & 20.3 & $>180$ \\
Dextromethorphan & 25.0 & 15.0 & 92.5 & 154 \\
$\mathbf{1 1}$ & 12.8 & 12.8 & $>180$ & $>180$ \\
$\mathbf{1 2}$ & 32.0 & 13.2 & 72.3 & 174 \\
\hline
\end{tabular}

${ }^{a}$ Microsomal Intrinsic Clearance $=\ln (2) /\left(\mathrm{T}_{1 / 2}\right.$ [microsomal protein $\left.]\right)$

${ }^{\mathrm{b}}$ Half life $=0.693 / \mathrm{-k}$

$0.3 \mathrm{mg} / \mathrm{mL}$ human microsomal protein was used 
Table 5. Caco-2 permeability data

\begin{tabular}{|ccccc|}
\hline Compound & $\begin{array}{c}\text { Mean A->B } \\
\operatorname{Papp}^{\mathrm{a}}(2 \mathrm{~h})\end{array}$ & $\begin{array}{c}\text { Mean B->A } \\
\operatorname{Papp}^{\mathrm{a}}(2 \mathrm{~h})\end{array}$ & $\mathrm{R} e^{\mathrm{b}}$ & Comments \\
\hline atenolol & 0.12 & 0.44 & 3.7 & low permeability \\
propranolol & 8.8 & 27.3 & 3.1 & high permeability \\
talinilol & 0.061 & 13.4 & 220 & P-gp efflux control \\
$\mathbf{1 1}$ & 16.4 & 15.9 & 0.97 & \\
$\mathbf{1 2}$ & 16.3 & 14.8 & 0.91 & \\
\hline
\end{tabular}

${ }^{\mathrm{a}}$ Papp is the apparent permeability rate coefficient $=(\mathrm{dQ} / \mathrm{dt}) /\left(\mathrm{C}_{0} \mathrm{~A}\right)$

$\mathrm{dQ} / \mathrm{dt}$ is the rate of permeation; $\mathrm{C}_{0}$ is the initial concentration of the compound $(10 \mu \mathrm{M})$;

$\mathrm{A}$ is the area of monolayer

${ }^{\mathrm{b}}$ Efflux ratio $(\mathrm{R} e)$ is: Papp (B->A)/ Papp (A-> B); A->B: Apical to Basolateral permeability

An $R e>2$ indicates a potential substrate for P-glycoprotein or other active transporters. 


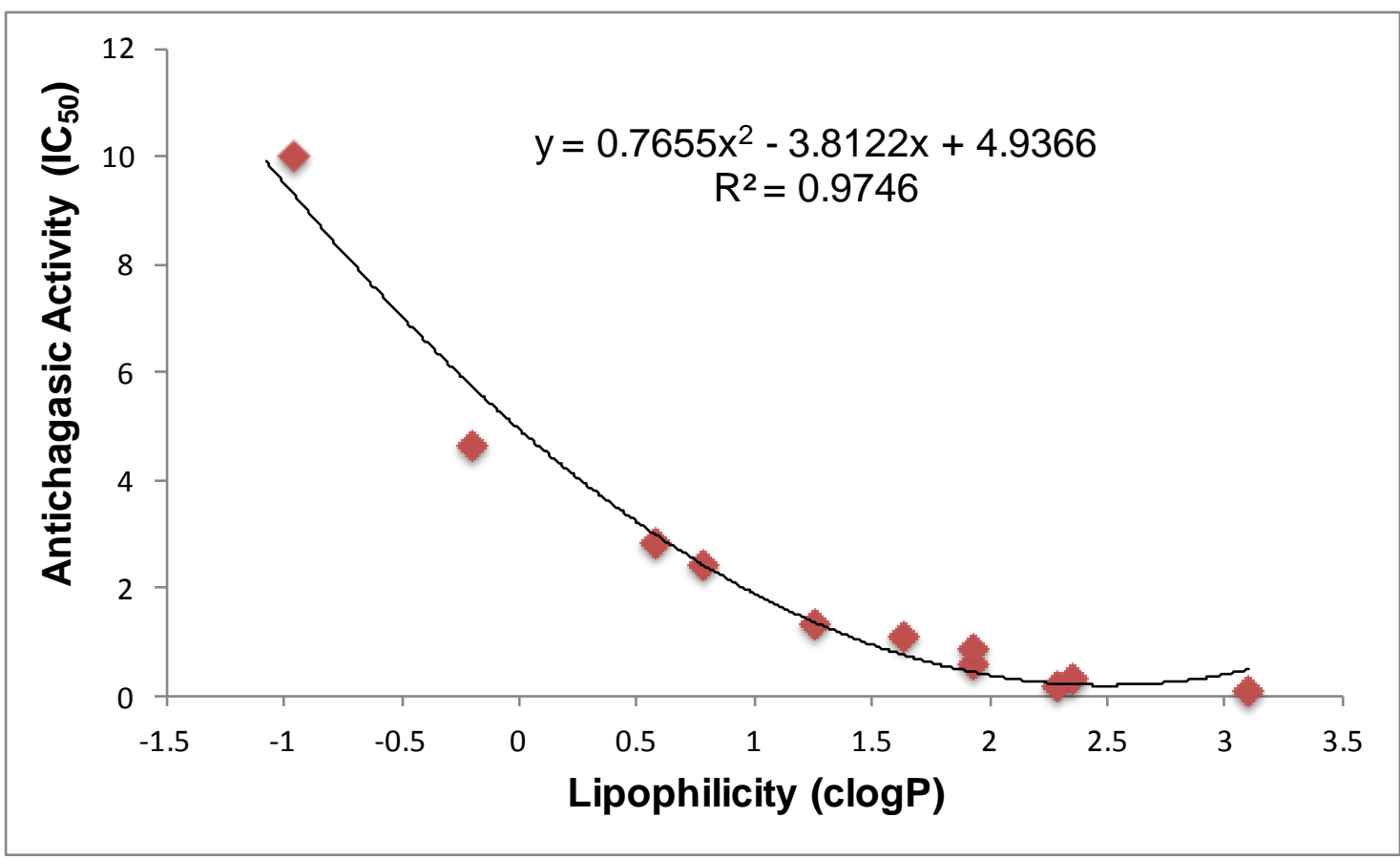

Fig. 1. Correlation graph between lipophilicity and antichagasic activity in the 3-nitrotriazolebased arylpiperazides. Compounds 2-9 and 11-13 were used. 


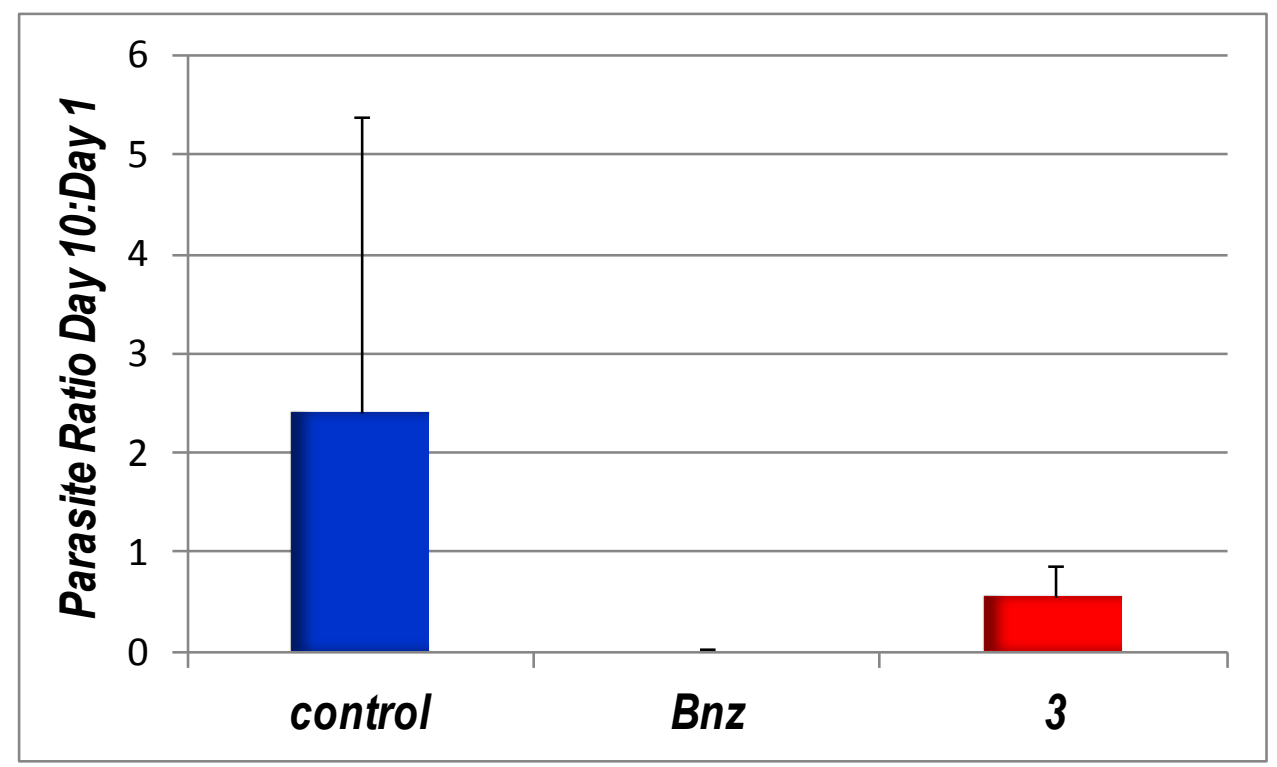

Fig. 2. In vivo evaluation of the antichagasic efficacy of compound $\mathbf{3}$ and benznidazole (Bnz) in an acute murine model. Compounds were administered (i.p.) at $15 \mathrm{mg} / \mathrm{kg} /$ day for 10 consecutive days. Parasite ratios were calculated on day 10. Groups of 5 mice/group were used. 
$\stackrel{\mathrm{RH}}{\mathrm{NH}}+\mathrm{ClCOCH}_{2} \mathrm{Cl} \stackrel{\mathrm{i}}{\longrightarrow}$

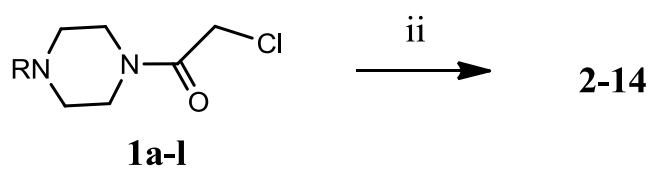

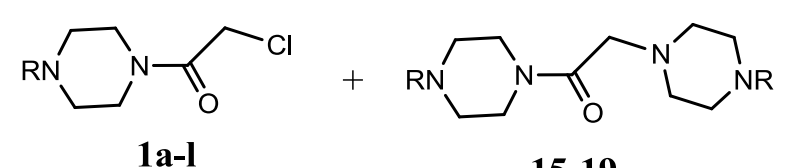

15-19

1g: $\mathrm{R}=\left[\begin{array}{c}\mathrm{N} \\ N\end{array}\right.$

1a: $\mathrm{R}=4-\mathrm{ClC}_{6} \mathrm{H}_{4}-$

1b: $\mathrm{R}=3,4-\mathrm{Cl}_{2} \mathrm{C}_{6} \mathrm{H}_{3}-$ 1c: $\mathrm{R}=4-\mathrm{CF}_{3} \mathrm{C}_{6} \mathrm{H}_{4}-$

1d: $\mathrm{R}=4-\mathrm{CH}_{3} \mathrm{C}_{6} \mathrm{H}_{4}-$

1e: $\mathrm{R}=4-\mathrm{CH}_{3} \mathrm{OC}_{6} \mathrm{H}_{4}$

1f: $\mathrm{R}=2-\mathrm{NCC}_{6} \mathrm{H}_{4}$
1h: $R=\mathbb{E}_{-N}^{N}$
1i: $\mathrm{R}=4-\mathrm{CF}_{3} \mathrm{C}_{6} \mathrm{H}_{4} \mathrm{CH}_{2}$
1j: $\mathrm{R}=3,4-\mathrm{Cl}_{2} \mathrm{C}_{6} \mathrm{H}_{4} \mathrm{CH}_{2}$
1k: 司四
11:

i) $\mathrm{Et}_{3} \mathrm{~N}, \mathrm{CH}_{2} \mathrm{Cl}_{2}, \mathrm{RT}$; ii) 3-Nitro-1,2,4-triazole/2-nitroimidazole, $\mathrm{KOH}, \mathrm{CH}_{3} \mathrm{CN}$, reflux $9 \mathrm{~h}$. 